THEMIS ARAGAO I WOLFGANG MAENNIG

MEGA SPORTING EVENTS, REALESTATE, AND URBAN SOCIAL ECONOMICS THE CASE OF BRAZIL 2014/2016

Urban Transport Media

Sports

Socio-

Regional

Real Estate

Architectural

ECONOMIC DISCUSSIONS

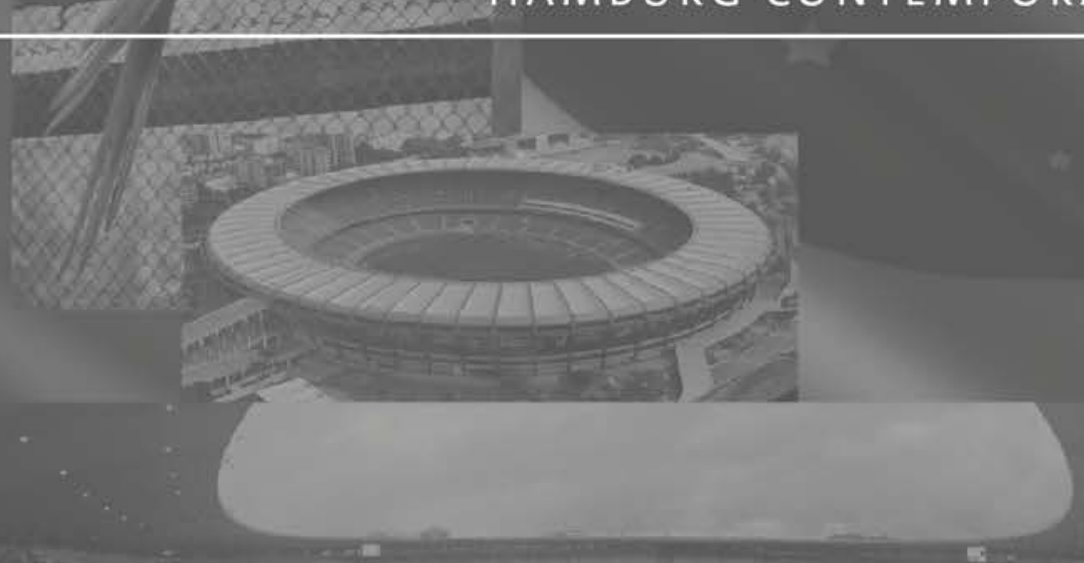




\section{Hamburg Contemporary Economic Discussions}

University of Hamburg

Faculty of Business, Economics and Social Sciences

Chair for Economic Policy

Von-Melle-Park 5

D-20146 Hamburg | Germany

Tel +49 $4042838-4622$

Fax $+494042838-6251$

http://www.uni-hamburg.de/economicpolicy/maennig.htm

Editor: Wolfgang Maennig

Thêmis Aragão

University of Hamburg

Faculty of Business, Economics and Social Sciences

Chair for Economic Policy

Von-Melle-Park 5

D-20146 Hamburg | Germany

Tel +49 4042838 - 6122

Fax $+494042838-6251$

themis.aragao@wiso.uni-hamburg.de

Wolfgang Maennig

University of Hamburg

Faculty of Business, Economics and Social Sciences

Chair for Economic Policy

Von-Melle-Park 5

D-20146 Hamburg | Germany

Tel +49 $4042838-4622$

Fax +494042838 - 6251

wolfgang.maennig@wiso.uni-hamburg.de

ISSN 1865 - 2441 (Print)

ISSN 1865 - 7133 (Online)

ISBN 978-3-942820-08-0 (Print)

ISBN 978-3-942820-09-7 (Online) 


\title{
Mega Sporting Events, Real Estate, and Urban Social Economics - The Case of Brazil 2014/2016
}

\begin{abstract}
These events promise to improve the urban quality of life and to induce social legacy because of investments in urban infrastructure, transportation, and sporting facilities. Our analysis of the case of Brazil, especially in Rio de Janeiro (host of the 2014 World Cup and 2016 Olympic Games) shows that such benefits may differ locally and may accentuate the process of socio-spatial segregation. Urban projects often include forced evictions of low-income populations and the consequent expansion of social segregation. In public opinion, mega events are also responsible for increasing rents and (real estate) prices. However, such inflationary phenomenon occurs in most Brazilian cities, including nonhost cities. The appreciation of real estate is explained largely by population and economic growth and the reduction of interest rates through mortgage programs, as well as reduced social inequality. Public investments in mega events account for only approximately 0.15\% of Brazilian GDP from 2007 to 2016 and are thus too small to be responsible for the (increasing) social problems.
\end{abstract}

Obviously, the perceived lack of public accountability for mega event finances as well as the perceived lack of susceptibility to social issues by the mega sporting projects may harm the public opinion of mega events. International sporting federations should thus have every interest in ensuring that their mega events target social inclusion and pay more attention to the needs of local urban and social policies.

Keywords: Housing Prices, Real Estate, FIFA World Cup, Olympics, Mega Sporting Events, Rio de Janeiro 2016, Urban Planning, Accountability.

Version: July 2013

\section{Introduction}

Many academic studies covering mega sporting events ask why such events gain so much importance in the agendas of many governments (Broudehoux, 2007; Gotham, 2005; Harvey, 2009; Arantes, Vainer and Maricato, 2000). Hiller and Wanner (2012) highlight two major interpretations. First, the Olympics are understood to be a transmission channel in which multinational corporations allied with the IOC can generate large amounts of cash with little public accountability (Short, 2008; Tomlinson, 2005). Second, hosting mega events can be considered a tool for urban development and entrepreneurialism (Cochrane et al., 1996; Essex and Chalkley, 2004; Gold and Gold, 2008). In an extension of both perspectives, the Olympics may also be interpreted as an instrument that can 
potentially benefit certain sectors and milieus that are forceful pressure groups within a community.

In Brazil, the real estate sector is one of the sectors that encourage the realization of mega sporting events. These events promise to improve the urban quality of life and to induce social legacy because of investments in urban infrastructure and transportation. Such (additional) benefits may differ locally and may accentuate the process of socio-spatial segregation, implying that the attitudes within the real estate sector may also differ locally.

The allocation of socially beneficial facilities, such as in the form of better infrastructure, generally may lead to increasing rents and prices and may thus be regarded poorly by tenants and potential buyers. It is therefore no wonder that the increasing prices and rents in Brazil in recent times have been associated with mega sporting events and that these price increases, in addition to the increase in transport prices, are targets of recent demonstrations. ${ }^{1}$

Section 2 describes the foundations of urban planning and city management upon which the realization of mega events in Brazil was justified. It also points to the socio-political dynamics involved in such an approach. Section 3 analyzes the historical development of the construction industry ${ }^{2}$ in Brazil, the strategies adopted for its promotion and the importance of mega events. Section 4 refers to the case of the city of Rio de Janeiro, which is the host city of the Pan-American Olympic Games 2007, the Confederations Cup 2013, the World Cup 2014, and the Summer Olympic Games 2016, summarizing the social context of the city during the run-up to the Olympic Games. Section 5 analyzes the housing market in

\footnotetext{
${ }^{1}$ http://www.ofluminense.com.br/editorias/cidades/procura-por-imoveis-sobe-27-em-cidadessede-da-copa-das-confederacoes (Accessed July 8, 2013),

http://www.oestadoce.com.br/noticia/copa-do-mundo-e-olimpiadas-como-os-eventos-refletiraono-setor-imobiliario (Accessed July 8, 2013),

http://clubehouse.com.br/noticias/alta-preco-imoveis-fortaleza-copa-mundo/ (Accessed July 8, 2013),

http://www.vanguardngr.com/2013/06/pomp-protests-as-confederations-cup-begins/ (Accessed July 8, 2013).

${ }^{2}$ In this paper, we consider the construction sector to be the group of companies related to building residential and commercial stock as well as infrastructure.
} 
Brazil, especially in Rio de Janeiro, verifying whether there is a relation between the increase in real estate prices and the realization of mega events.

\section{Mega Sporting Events: Brazilian Development Strategy and Urban Social Dynamics}

In the Brazilian context, standard urban development management practices were technocrat-centered until the mid-1980s. With the demise of authoritarian management policies, new models of development have been disseminated by the major multilateral agencies for Latin America (World Bank, Habitat Agency, BID). Among the urban planning models propagated for Brazilian cities, the “Strategic Planning" model (Borja and Castells, 1997), which had previously been applied for the Barcelona 1992 Olympic Games ${ }^{3}$, was influential. Throughout the 1990s, this strategy was reflected in the large number of Brazilian cities that made their urban plans by Catalan consultancy or its affiliates. ${ }^{4}$

This methodology assumes that the city plays an important role in the determination of capital flows. City marketing gains more weight, and "making the city competitive" becomes a major goal of local governments (Vainer, 2000). Competitiveness in this scenario is understood as the characteristic of an environment/space by which capital is attracted and to be fixed under the best conditions of profitability.

In addition, it is up to local governments to internally promote the city to "provide 'civic patriotism' for the inhabitants, the sense of belonging, of collective will, of participation and trust and belief in the future of the metropolis" (Borja and Castells, 1997). This ideological aspect is part of the strategy to neutralize social conflicts between underserved social segments and the economic agents interested in private returns. Achieving consensus between the groups involves cooperation and minimizing conflicts. Ideologically, evictions, the privatization of

\footnotetext{
${ }^{3}$ It was performed through the publishing of large volumes of materials by the Regional Office for Latin America and the Caribbean of the Urban Management Program, with the goal of disseminating information about the experience of Barcelona (Arantes, Vainer and Maricato, 2000).

${ }^{4}$ Among the main Brazilian cities that have developed their strategic plans are Rio de Janeiro (1993), Recife (1998), Fortaleza (1997), Belém (2002), Juiz de Fora (1997) and Vitória (1996).
} 
collective equipment and environmental damage become acceptable elements in the game of global competition. One important feature of this type of urban entrepreneurialism is the attraction of mega events ${ }^{5}$ through construction of convention centers and sports arenas. Another one is there modeling of historic centers and harbor areas. These projects replace traditional urban planning ${ }^{6}$. In the logic of competitiveness, improving the business environment is the main objective, and the population benefits from the effects of policies on investment attraction. In theory, the public welfare is a consequence of the increase in economic activities, and the gains of this process are naturally socialized.

Within this strategy of urban entrepreneurialism, the hosting of mega sporting events has historically played a central role. In 1996, Rio de Janeiro applied to host the 2004 Summer Olympic Games. On this postulation, Rio de Janeiro cited tourism as the city's major appeal. However, the initiative failed, leading Brazil to rethink strategies for hosting mega events.

The Brazilian Olympic directors understood that the best way to refute the argument that Brazil would not be a competent host city for the Summer Olympic Games would be to host a mega event. This was a major reason that propelled the Brazilian Olympic Committee and the Ministry of Sports to submit an application for the city of Rio de Janeiro to host the 2007 Pan American Games (Rubio, 2010). During the run-up to the Pan-American Games, approximately 1.8 billion reais ${ }^{7}$ (around US\$934 million in 2007) were invested in infrastructure and

\footnotetext{
${ }^{5}$ Mega events means an event (short duration) that demands a great infrastructure in the city to receive a big public. Mega events involve sport tournament, big conferences, religious events, international exhibitions, political meeting, etc. Although sport events have more academic production, it is considered a category of mega event.

${ }^{6}$ In traditional urban planning framework, there is a hierarchical relationship between project and plan. Project is a tool of a plan. The plan is the result of planning process. Planning, in its turn, involves principles of social equity, environmental control, mediation between various political actors and integrated vision of the whole urban habitat. The project has punctual and fragmented character and is thought within a given context and benefiting certain interests. The discussion with regard to the division of resources in the city and the needed of the project in relation to the demands of the city are not considering. The project exists at its own convenience, depending on social, political and economic forces.
}

${ }^{7}$ The initial investments planned for the games were around 95 million Reais, finally reaching the amount of 1.8 billion Reais (approximately $\$ 842$ million) in 2007, as indicated by the Federal Audit Court Report. 
real estate projects. Despite some mishaps, the completion of the Pan-American Games was considered a success and gave Brazil the advantage in the race to host other events.

After the fulfillment of Pan-American Games, Brazil was confirmed in 2007 as the host of the 2014 FIFA World Cup. Twelve state capital cities in the country were chosen to host the World Cup. ${ }^{8}$ A public investment of US\$12.2 billion was planned for the construction of sports arenas and urban infrastructure.

Fig. 2.1 World Cup Cities and Other Capital Cities

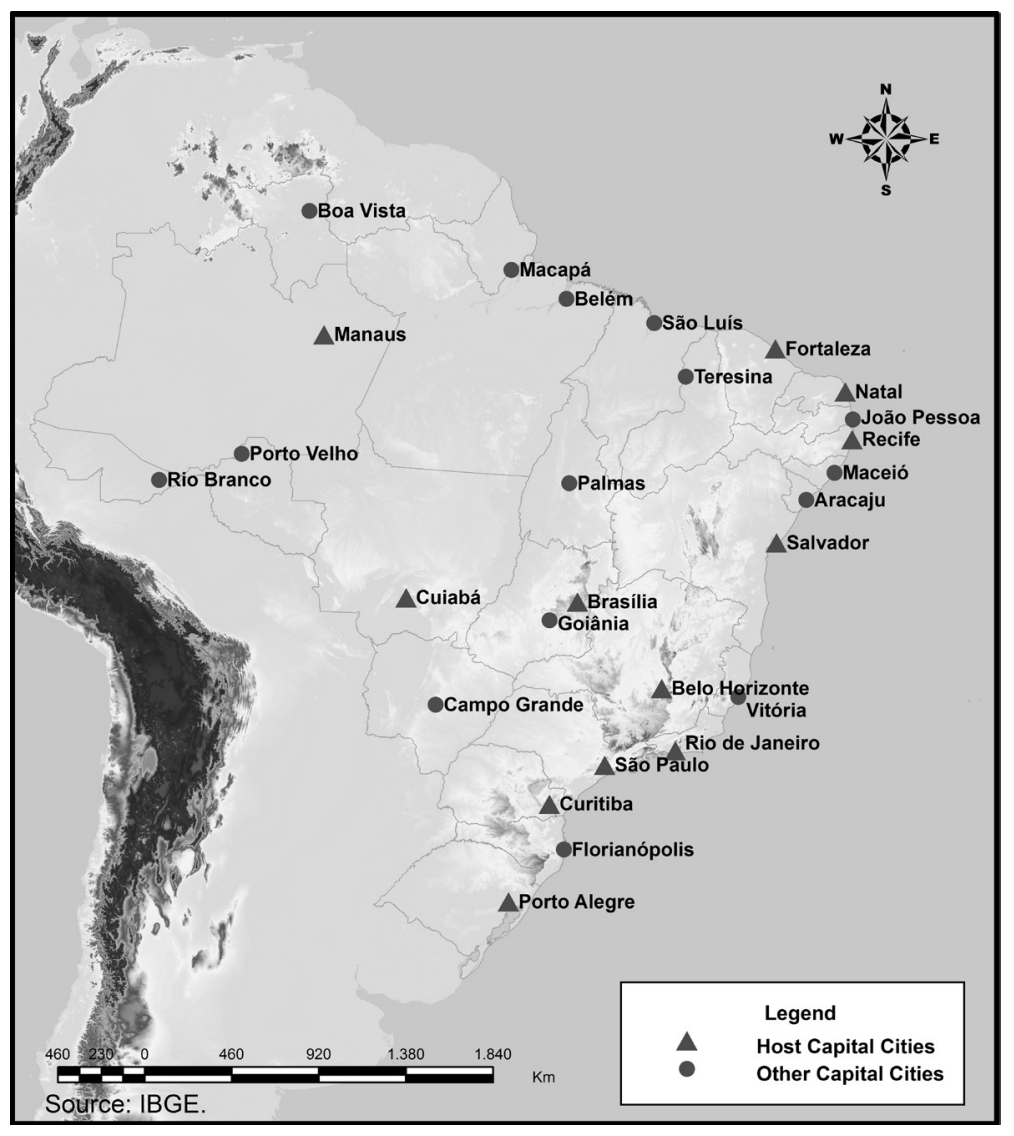

Considering these projects surrounding mega sporting events and the investments in sports facilities, significant changes in the urban dynamics are in progress in the run-up to these events, involving processes of gentrification, segregation and commodification of the city (Harvey, 2009). Politicians adapted their agendas within the legislative sphere to aid in the promotion of these mega events. The perceived increase in the number of decrees and provisional

\footnotetext{
${ }^{8}$ Manaus, Fortaleza, Natal, Recife, Salvador, Cuiabá, Brasília, Belo Horizonte, Rio de Janeiro, São Paulo, Curitiba and Porto Alegre.
} 
measures, as well as an entanglement of ordinances and resolutions, sometimes ran the risk of violating the principles of impartiality, universality and publicity of the law and acts of public administration. An example of this phenomenon involves the suspension of the state law that bans the consumption of alcoholic drinks in football stadiums and the annulment of the laws that protect the architectural and historical patrimony of the Sambódromo and Maracanã Stadium. The cancellations and suspensions of these laws occurred due to an emergency bill sent by the governor to the Legislative Assembly. Due to the "urgency" requested and the political agreements that were made with the government base in the Legislative Assembly, the cancellations were approved without going through the normally mandatory steps of public debate. With that, the Sambódromo and Maracanã Stadium were demolished, and another stadium project commenced. The realization of the World Cup and the Olympics may thus emerge as justification to compress community participation in development projects:

"These changes (zoning) took place through an unexpected "flash-vote" in the City Council, which approved the legislative amendment in anti-democratic molds, excluding any possibility of popular participation, referred to in the Master Plan of the city itself, and thereby avoiding any chance of the proper consideration by all councilors voting." (Gaffney and Omena, 2010)

Moreover, the government may prioritize the physical goals of these projects while neglecting their social impact. An illustrative example is that of the Alemão Complex, where, after receiving a core of infrastructure investments, the president of the Residents Association and 416 other families were expelled from the community because they could not afford the rents that had risen by more than $100 \%{ }^{9}$ In Braziliantenancy law, the owner may request the property of the tenant at any time, giving a deadline of three months for the tenant to find

\footnotetext{
${ }^{9}$ An article published in the journal O Dia January 30, 2013. Title: Prices in Alemão Complex doubles and 417 families have 15 days to leave property. http://odia.ig.com.br/portal/rio/pre\%C3\%A7os-no-alem\%C3\%A3o-dobram-e-417fam\%C3\%ADlias-t\%C3\%AAm-prazo-de-15-dias-para-deixar-im\%C3\%B3veis-1.541575 (Accessed July 8,2013$)$.
} 
another home. With this mechanism, the property may, in a short amount of time, adjust to the changing prices of the rental market.

Urban legislation and investment in infrastructure and housing can even be understood as a process of urban spoliation (Kowarick, 1979), especially as a process of accumulation by dispossession (Harvey, 2009). Urban spoliation happens when wage levels do not suffice to cover the costs of reproduction of the labor force. The labor force may then seek to compensate the gap by constructing socialities outside the formal model, materialized in the formation of slums, illegal trade or drug trafficking, among other ways.

Urban accumulation by dispossession may be equivalent to an appropriation of collective property by private groups: "What accumulation by dispossession does is to release a set of assets (including labor power) at very low cost (and in some cases zero). The over-accumulated capital can take possession of these assets and make them immediately profitable. In the case of primitive accumulation that Marx described, this means taking the land, encircle it and expelling the resident population to create a landless proletariat, then transferring the land to the privatized mainstream of capital accumulation. Privatization (social housing, telecommunications, transport, water etc., in England, for example) have opened in recent years large fields to be appropriated by the over-accumulated capital" (Harvey, 2009).

Mega sporting events may enhance such accumulation processes. The Maracanã Complex was renovated for the Pan-American Games 2007, with an initial (public) budget of $\mathrm{R} \$ 304$ million. Three years later, under the justification to fulfill FIFA requirements, the stadium was demolished and rebuilt with an additional cost of R\$1.049 billion of public investment. Additionally, the management of Maracanã Stadium was privatized for an amount of $\mathrm{R} \$ 181.5$ million. The private consortium that won the bid will manage the equipment for the 35 years before the 2014 World Cup The practice of privatization of public equipment within the logic of "sustainability" is not limited to stadiums but includes airports, ports and housing policy itself. 
During the rebuilding of Maracanã Stadium, it was necessary to demolish a school to allow for the construction of a parking garage, and the nearby water park has also been slated for complete demolition. The Indian Museum, one of the oldest buildings in Rio de Janeiro and the first indigenous museum in Latin America, was not demolished because of great social mobilization. This process of urban spoliation helped to spur several demonstrations in 2013 against mega events in Brazil.

\section{Housing Policy of the Brazilian State}

Today's Brazilian housing market and its financing are heavily influenced by the Housing Finance System (HFS), which was started in 1964 and is the principal resource for financing infrastructure and housing stock in the country. It is constituted of two main sources: the Guarantee Fund for Length of Service (FGTS) and the Brazilian System of Savings and Loans (SBPE). ${ }^{10}$

The housing production cycle that started in 1964was interrupted in the 1980s, mainly due to the drastic reduction in credit offered by HFS (Fig. 3.1) in the wake of the Mexican financial crisis and the ending of the "developmentalist period" (Pereira, 1990). Although housing credit decreased, inflation in the country sharply increased from around $40 \%$ in the 1960 s and 1970 s to $330 \%$ in the 1980 s and jumped to more than $760 \%$ in the period between 1990 and 1994 (Haddad and Meyer, 2012).

\footnotetext{
${ }^{10}$ The Guarantee Fund for Length of Service (FGTS) was created in the 1960 s to protect employees dismissed without just cause. It is a compulsory deposit held by the employer on behalf of their employees, linked to the employment contract, with a value corresponding to $8 \%$ of the salary of each employee. The Brazilian System of Savings and Loans (SBPE) consists of real estate credit societies, savings and loan associations, real estate portfolios of state savings banks, the Caixa Econômica Federal and multiple banks that collect savings deposits as a form of voluntary financial application. The directing resources guidelines are established by the National Monetary Council and monitored by the Central Bank. To manage the application of the resources of HFS, the National Housing Bank (BNH) was created.
} 
Fig. 3.1 Number of Units Financed by the Housing Finance System

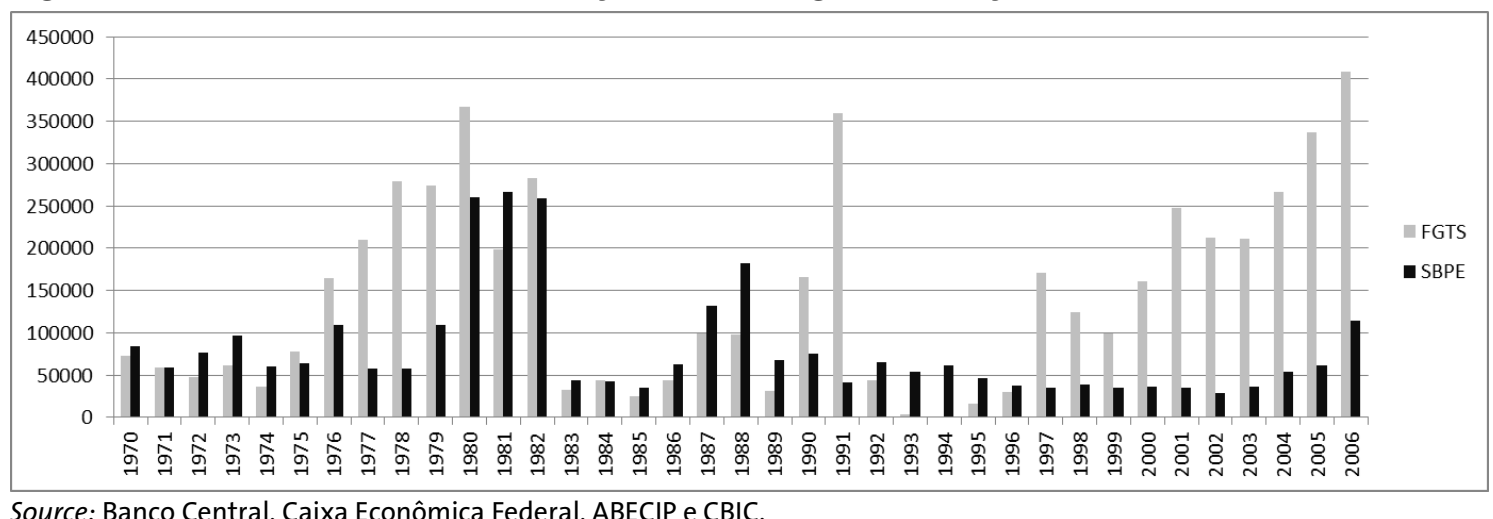

To combat the economic crisis, the government launched the Real Plan in 1994, which stabilized the economy in a short period of time. In addition to the price stabilization that occurred at the end of the 1990s, regulatory changes have allowed the use of securitization mechanisms in the real estate business. In 1997, the Real Estate Financial System (SFI) was created. The SFI established the mechanism of Real Estate Investment Funds (FII) and Certificates of Real Estate Receivables (CRI). With this, the HFS was able to refinance itself in capital markets (Haddad and Meyer, 2012).

Despite the economic stabilization that occurred at the end of the 1990s, civil construction companies were not convinced to expand housing production. However, the federal government at the time did not decrease the interest rate or expand mortgage programs. Only in 2005, with a solid economic scenario and the increased purchasing power of the population, did the context become favorable for the incremental increase of real estate stock. With this, the civil construction industry began the process of restructuring, and many companies went public. The funds raised in capital markets caused greater diversification among builders. By December 2007, 29 building companies were listed in the stock exchange. The IPO of real estate companies injected more than $\mathrm{R} \$ 12$ billion (around US\$6.2 billion) into the sector (Haddad and Meyer, 2012).

To increase production, the area of operation of these companies was expanded, moving into new regions and new markets. The nationalization of the housing market depended crucially on the association between national real estate companies and small, local construction firms, which had strong expertise in 
project approval, control over the workforce and knowledge of the target audience.

Despite this positive scenario for real estate in Brazil, real estate companies suffered setbacks as a result of the US subprime crisis. On this point, action was necessary to ensure the trustworthiness of businesses from the perspective of the international market. Inspired by the experiences of Mexico and Chile, the Union of Employers of Civil Construction (SINDUSCON) drafted a new program of mortgages and presented it to the Minister of Civil Housing at the time, Dilma Rousseff.

In March 2009, the federal government announced the My House My Life Program (PMCMV), a program of housing mortgages for families with incomes up to 10 times the minimum wage $(\mathrm{MW})$. The program set a goal of funding one million housing units and $\mathrm{R} \$ 30$ billion of subsidies (ca. to US\$1.4 billion). Two years later, the program was relaunched with the name My House My Life 2, expanding the target to two million units. The guarantee of a mortgage program neutralized the effects of the subprime crisis and helped building companies that made IPO. The BM\&FBOVESPA Real Estate Companies Index (IMOB) measures the price of real estate companies' shares. Compared with the BOVESPA index it is verified that companies in the real estate market declined sharply during the subprime crisis and recovered after the launch of MCMV in March 2009. (Fig. 3.2).

Fig. 3.2 BM\&FBOVESPA Real Estate Companies Index (IMOB)

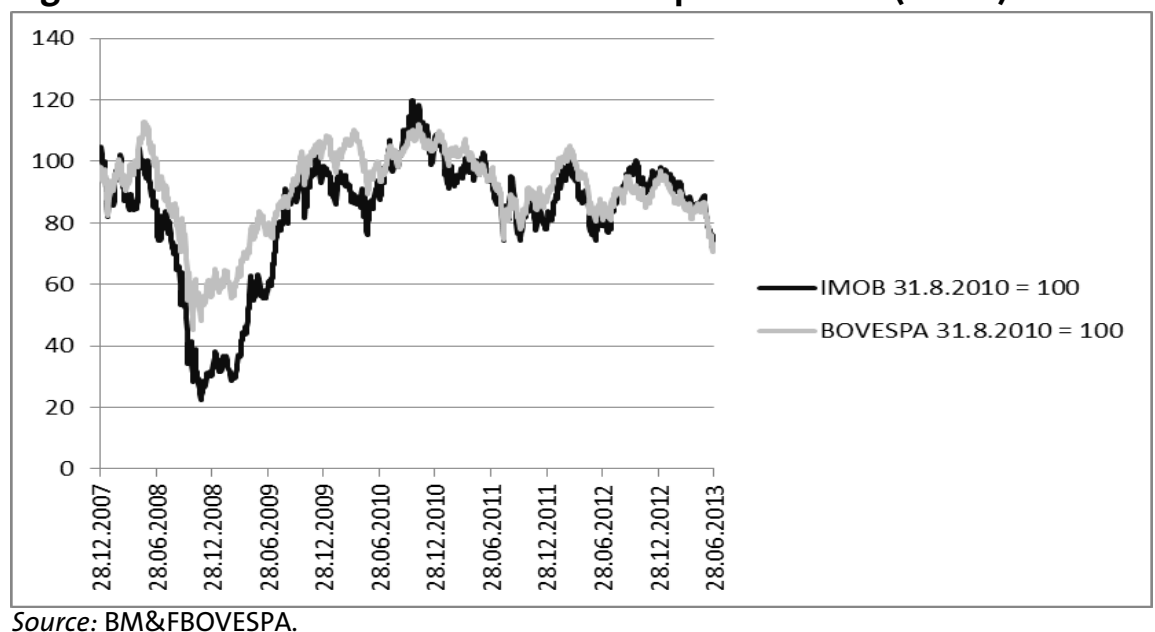


Considering the process of housing market oligopolization, until 2011, ten companies were responsible for $15 \%$ of all housing units constructed by the My House My Life Program throughout Brazil, and six of these companies were public (Cardoso, Aragão and Araújo, 2011). According to the Annual Survey of Construction Industry (IBGE), Brazil registered 40,644 active construction companies working in the field of buildings and infrastructure in 2011. Nevertheless, only $3.65 \%$ of these companies received financing from the My House My Life program.

Investments in the construction sector were not restricted to the construction of houses through the My House My Life Program. In addition to the Housing Financial System resources, with the Guarantee Fund for Length of Service (FGTS), the local and state governments directly invested the public budget into highways and public facilities (stadiums, sports arenas and urban renewal). For the year 2013, the federal government planned to invest 47.7 billion $\mathrm{R}^{11}$ for construction related to logistics and energy (e.g., hydroelectric dams, ports, airports, highways).

Fig. 3.3 Amount of Resources Invested by the FGTS (mill. R\$)

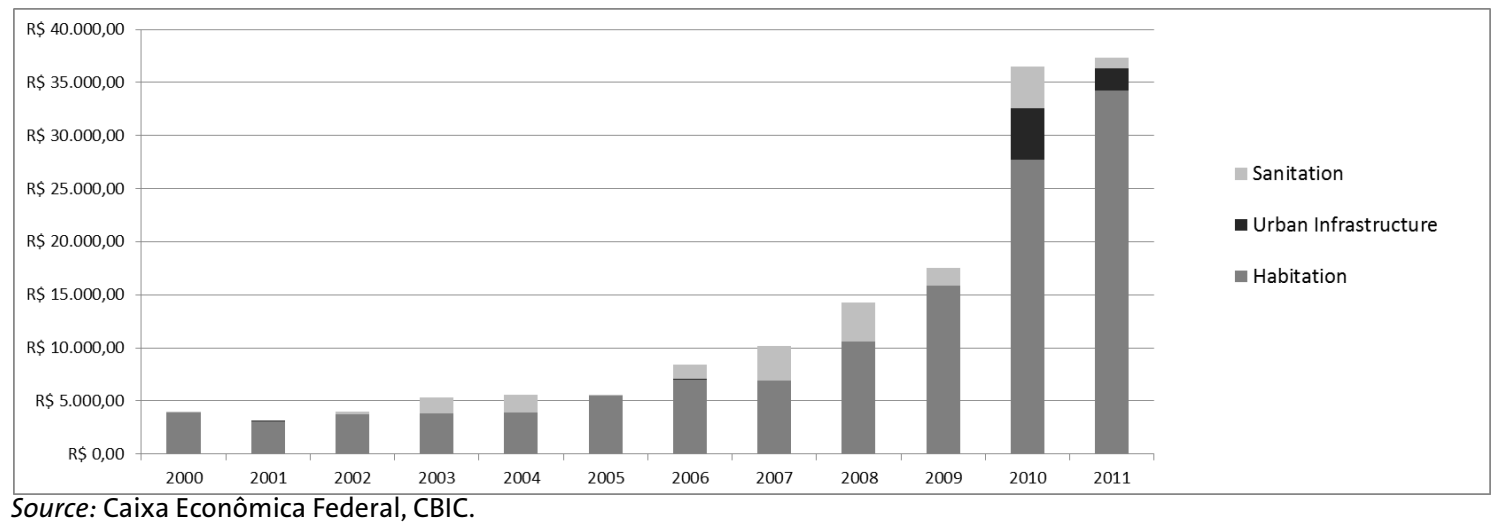

Note that the electoral system allows the influence of economic sectors in public policy due to the candidates' dependence on private campaign donations. In 2010 elections, the civil construction companies, representing approximately $33.73 \%$ of the total financing, were the biggest contributors to campaign finance, totaling $\mathrm{R} \$ 766$ million (around US\$422 million). Eleven building companies donated some

\footnotetext{
${ }^{11}$ Data from the Ministry of Planning and Budget (2013).
} 
R\$387million (around US\$215 million), and all of them signed government contracts to perform construction related to the World Cup or Olympics. ${ }^{12}$

\section{Rio de Janeiro's Urban Development Strategy in the Run-Up to the World Cup and the Olympics}

One of the requirements of international organizations such as FIFA and the International Olympic Committee concerning mega sporting events is the guarantee that the events will occur on schedule, including decent accommodation, good transportation conditions and safety for the participants. ${ }^{13}$ In a setting where a large part of social demands is unfulfilled in the city as a whole, the strategic plan proposes a paradoxical response: implementing general interest improvements that will only be available for some parts of the city.

In the case of Rio de Janeiro, the second largest city in Brazil, the processes of resource concentration and urban segregation are illustrative. The city of Rio de Janeiro has been the scene of several projects designed to prepare the city for mega events. ${ }^{14}$ The construction works have included sporting venues and infrastructure in the field of urban restructuring projects and mobility, including modernization and expansion of the subway, construction of bus lines and renovation of the Tom Jobim International Airport.

According to the 2010 census, Rio de Janeiro has a population of 6,320,446 inhabitants and a stock of 2,144,463 permanent housing units, consisting of 73.11\% owner-occupiers. The housing deficit in Rio de Janeiro, calculated by João Pinheiro Foundation through PNAD (2008), is 522,607 units (24.37\% of Rio de Janeiro's housing stock), while the lack of infrastructure ${ }^{15}$ reaches 880,752 residents $(41.07 \%)$.

\footnotetext{
${ }^{12}$ Systematized data from the database of Superior Electoral Court.

${ }^{13}$ Matrix of responsibilities between the Union and States (Brazilian Sport Ministry) and Olympic Charter - Published by the International Olympic Committee - July 2011.

${ }^{14}$ Pan-American Games (2007), Military Olympics Games (2011), United Nations Conference on Sustainable Development RIO+20 (2012), World Meeting of Youth and Pope's visit (2013), Confederation Cup (2013), World Cup (2014) and Olympic Games (2016).

${ }^{15}$ The housing need in Brazil is composed of the quantitative and qualitative deficit. The first is related to the addition of stock due to population growth, cohabitation and replacement of
} 
One of the major discourses used to justify hosting mega sporting events is the social legacy for the city. Considering the process of economic growth and the availability of credit to build social housing in the country, the expected result would be the reduction of social inequalities. Nevertheless, urban mobility projects the renovation of surroundings of sporting venues, often including forced evictions of low-income populations and the consequent expansion of social segregation. In the case of Rio de Janeiro, only a small portion of the removed families remained close to their places of origin (Fig. 4.1).

Fig. 4.1 Map of Evictions from the Interventions Related to the World Cup and the Olympics in Rio de Janeiro, 2011

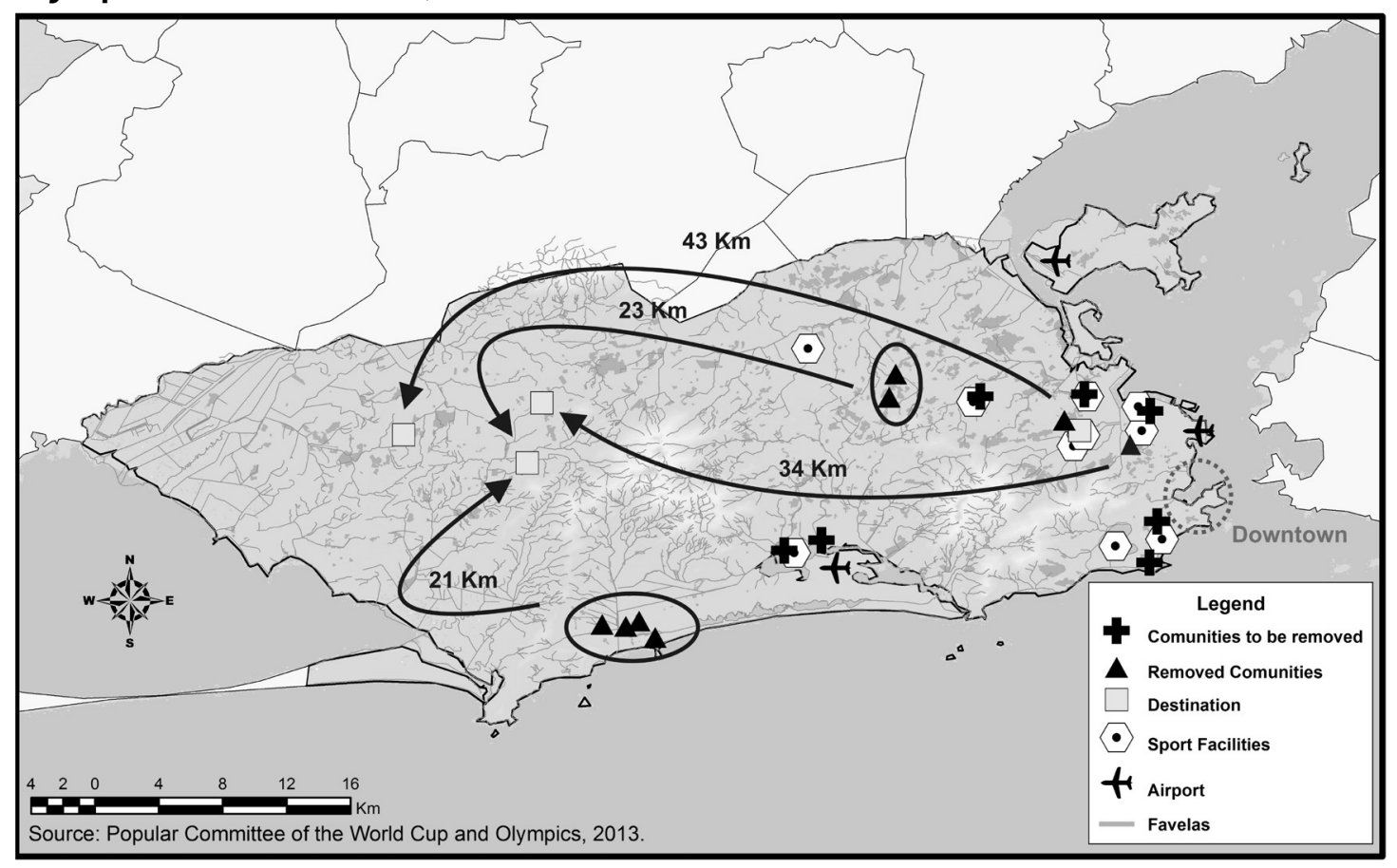

The process of eviction towards the western region of Rio de Janeiro, an area characterized by poor infrastructure, results in increased transportation costs ${ }^{16}$ from home to work for the evicted persons and promotes spatial mismatch ${ }^{17}$

properties inappropriate for housing. The qualitative deficit is characterized by the lack of basic infrastructure such as water supply, sanitary sewage, waste disposal or absence of bathroom. Thus, the main components of housing policy are the construction of new units and slum urbanization.

${ }^{16}$ During removal, the city transport system was not yet integrated, requiring the payment of extra tickets if the person needed to change buses to reach their destination.

17 Spatial mismatch is the sociological, economic and political phenomenon associated with economic restructuring in which employment opportunities for low-income people are located far from the areas where they live. In Rio de Janeiro, a large portion of job opportunities are offered in the downtown area. 
(Kain, 1968; Cutler and Glaeser, 1997; Weinberg, 2000). In removed families, a large number of children had problems finding schools in their new neighborhood because the schooling infrastructure did not absorb the population growth in the neighborhood (Cardoso, Aragão and Araújo, 2011). Some of the children remained in their former schools, but most families that did not have enough money for transportation decided to skip the school year until they found a place for their child in the neighborhood school. In the meantime, the children remained out of school. ${ }^{18}$

There are no official data on evictions. For Rio de Janeiro, the Popular Committee of the World Cup and the Olympics identified 7,185 families that have been affected or threatened by interventions related to mega events. In other cities, even families that are not located on the perimeter of sports venues are being removed under the justification that tourist areas cannot accommodate slums. All over Brazil, the Popular Committee of the World Cup estimated that 170,000 families will be removed as a result of the planning for the World Cup and Olympics. $^{19}$

Another form of (perceived) segregation is due to the structure of My House My Life program. Analyzing its loans, until March 2011, the construction of 31,225 housing units were financed in the city of Rio de Janeiro alone, providing 16,171 units to families who earn between 0 and 3 times the minimum wage, 4,559 to families receiving between 3 and 6 times the minimum wage and 10,495 to families receiving between 6 and 10 times the minimum wage. ${ }^{20}$ Because the construction of housing through the My House My Life program is held by the private sector, the location of the housing units follows the spatial structure of

\footnotetext{
${ }^{18}$ Although parents have the obligation to keep children in school, the collection of children by the government only happens when the cause of school evasion is not related to a deficiency in public services. In the case of school evasion caused by forced evictions, the judicial apparatus turns against the government, to the extent that the State should have prepared a plan for removal, ensuring the supply of public social services to the population removed. In Rio de Janeiro case, the family that found no place in the neighborhood school should have sued the state to have their rights guaranteed (Statute of the Child and Adolescent - Law No. 8069 of 13 July 1990).

${ }^{19}$ Report of Popular Committee of the World Cup, political articulation of civil society responsible for collecting data sent by social movements in Brazil.

${ }^{20}$ Source: Caixa Econômica Federal, 2011.
} 
the land price, implying the allocation of low-income families on cheap land around the periphery of the city due to a lack of urban infrastructure and public services. Fig. 4.2 illustrates this increase of social inequalities in the urban space as a consequence of the absence of the direct action of the state in the construction of social housing.

Fig. 4.2 Project Distribution of the My House My Life Program

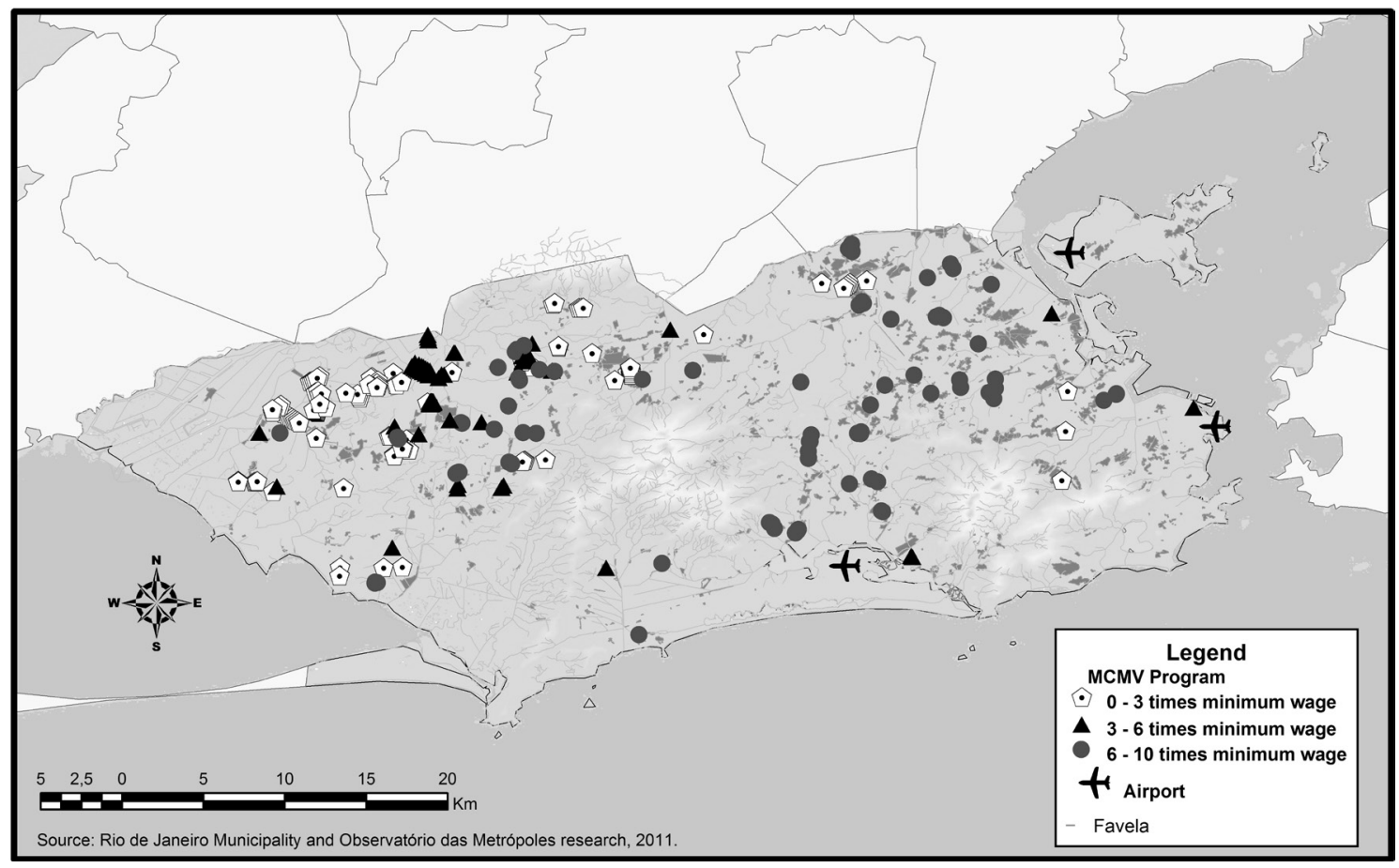

\section{Brazilian Real Estate Prices: Development and Determinants}

There is a widespread intuition in Brazil that real estate prices have become "unaffordably" high, and there is common sense that the World Cup and the Olympics take some responsibility for this phenomenon ${ }^{21}$.

There is indeed evidence that Brazil experienced internationally exceptional price acceleration in recent months and years. The Knight Frank 2012 global house price index shows that Brazil is the third-highest ranked country in the world and ranks first among countries in the Americas in the rate of rising home prices (Tab. 5.1).

\footnotetext{
${ }^{21}$ http://www.brasilwiki.com.br/noticia.php?id_noticia=47662(Accessed July 8, 2013); http://www.vooz.com.br/noticias/copa-do-mundo-e-olimpiadas-valorizam-aluguel-deimoveis-33062.html (Accessed July 8, 2013), http://www.globalpropertyguide.com/LatinAmerica/brazil/Price-History (Accessed July 8, 2013).
} 
Tab. 5.1 Knight Frank Global House Price Index

\begin{tabular}{|c|c|c|c|c|c|}
\hline Rank & Country & \begin{tabular}{|c|} 
12-month \\
\% change \\
(04 2011-04 2012)
\end{tabular} & $\begin{array}{c}\text { 6-month } \\
\text { \% change } \\
\text { (02 2012-04 2012) } \\
\end{array}$ & $\begin{array}{c}\text { 3-month } \\
\text { \% change } \\
\text { (03 2012-04 2012) }\end{array}$ & $\begin{array}{l}\text { Latest data, if } \\
\text { not Q4 } 2012\end{array}$ \\
\hline 1 & Hong Kong ${ }^{1}$ & $23.6 \%$ & $11.2 \%$ & $6.3 \%$ & \\
\hline 2 & Dubai, UAE & $19.0 \%$ & $9.8 \%$ & $8.9 \%$ & \\
\hline 3 & Brazil $^{2}$ & $13.7 \%$ & $5.8 \%$ & $2.7 \%$ & \\
\hline 4 & Turkey & $10.5 \%$ & $3.5 \%$ & $1.2 \%$ & \\
\hline 5 & Russia & $10.2 \%$ & $3.9 \%$ & $1.4 \%$ & \\
\hline 6 & Austria & $10.1 \%$ & $0.2 \%$ & $0.7 \%$ & Q3 \\
\hline 7 & Taiwan & $9.7 \%$ & $3.3 \%$ & $2.0 \%$ & \\
\hline 8 & China $^{3}$ & $9.3 \%$ & $3.7 \%$ & $0.1 \%$ & \\
\hline 9 & India & $8.5 \%$ & $6.0 \%$ & $5.3 \%$ & \\
\hline 10 & Colombia & $8.3 \%$ & $7.7 \%$ & $2.3 \%$ & Q3 \\
\hline 11 & South Africa & $7.4 \%$ & $6.2 \%$ & $2.5 \%$ & \\
\hline 12 & United States & $7.3 \%$ & $1.8 \%$ & $-0.3 \%$ & \\
\hline 13 & Malaysia & $7.3 \%$ & $1.3 \%$ & $-1.8 \%$ & O3 \\
\hline 14 & Indonesia & $7.0 \%$ & $4.9 \%$ & $3.8 \%$ & \\
\hline 15 & New Zealand & $6.7 \%$ & $3.6 \%$ & $2.3 \%$ & \\
\hline 16 & Norway & $6.6 \%$ & $-0.2 \%$ & $-0.7 \%$ & \\
\hline 17 & Estonia & $5.4 \%$ & $2.9 \%$ & $0.3 \%$ & \\
\hline 18 & Iceland & $4.6 \%$ & $1.4 \%$ & $0.7 \%$ & \\
\hline 19 & Israel & $4.5 \%$ & $1.5 \%$ & $-1.0 \%$ & \\
\hline 20 & Switzerland & $3.9 \%$ & $3.5 \%$ & $1.0 \%$ & \\
\hline 21 & Finland & $3.7 \%$ & $1.9 \%$ & $0.0 \%$ & \\
\hline 22 & Mexico & $3.1 \%$ & $1.2 \%$ & $0.0 \%$ & \\
\hline 23 & Canada & $3.1 \%$ & $-0.5 \%$ & $-1.0 \%$ & \\
\hline 24 & Singapore ${ }^{4}$ & $2.6 \%$ & $2.3 \%$ & $1.8 \%$ & \\
\hline 25 & Czech Republic & $2.5 \%$ & $-0.3 \%$ & $0.6 \%$ & \\
\hline
\end{tabular}

From the macroeconomic perspective, real estate prices are mainly determined by construction costs, income per capita, interest rates and population growth (Mankiw and Weil, 1989). ${ }^{22}$ Regional differences and shifts may also play a role on a disaggregated level-prices may depend on the agglomeration density, the political function of an agglomeration, and the local share of housing area (Dust and Maennig, 2007). The realization of mega events such as the World Cup and the Olympic Games may constitute an argument for increasing prices and investment in real estate in Brazil because of the positive external effects of the additional infrastructure. ${ }^{23}$

Furthermore, demand and the consequent price of housing maybe determined by changes in the distribution of housing. Brazil belongs to the group of countries that have the most unequal income distribution (Tab. 5.2, World Bank 2013). Over the last decade, this scenario has been constantly changing, and the reduction of social inequality contributed to the increase in demand for social housing. According to the Institute of Applied Economic Policy (IPEA 2012), the wages of the poorest 10\% of the Brazilian population grew 91.2\% between 2001 and 2011.

\footnotetext{
${ }^{22}$ Brazil's population grew by $1.17 \%$ p.a. in the last decade (IBGE - Census, 2010).

${ }^{23}$ http://www.theinformationcompany.net/a-report-about-real-estate-investments-in-brazil/

http://en.el-emergente.com/latin-america/brazil/why-rios-real-estate-market-could-be-anolympic-winner/
}

http://www.landcorpinternational.com/invest-in-brazil/about-brazil/investing-in-brazil/. 
The movement includes approximately 23.4 million people who have risen out of poverty. The income of the richest $10 \%$ rose by $16.6 \%$ over the same period. The inequality measured by the Gini coefficient declined from 59.4 in 2001 to 51.9 in 2012.

Tab. 5.2 - Ranking of the Most Unequal Distributions of Family Income

\begin{tabular}{|r|l|c|c|}
\hline Rank & Country & $\begin{array}{c}\text { Distribution of Family } \\
\text { Income GINI INDEX }\end{array}$ & Date of Information \\
\hline 1 & Lesotho & 63.2 & 1995 \\
\hline 2 & South Africa & 63.1 & 2005 \\
\hline 3 & Botswana & 63.0 & 1993 \\
\hline 4 & Sierra Leone & 62.9 & 1989 \\
\hline 5 & Central African Republic & 61.3 & 1993 \\
\hline 6 & Namibia & 59.7 & 2010 \\
\hline 7 & Haiti & 59.2 & 2001 \\
\hline 8 & Colombia & 58.5 & 2011 \\
\hline 9 & Honduras & 57.7 & 2007 \\
\hline 10 & Guatemala & 55.1 & 2007 \\
\hline 11 & Hong Kong & 53.7 & 2011 \\
\hline 12 & Thailand & 53.6 & 2009 \\
\hline 13 & Paraguay & 53.2 & 2009 \\
\hline 14 & Bolivia & 53.0 & 2010 \\
\hline 15 & Chile & 52.1 & 2009 \\
\hline 16 & Panama & 51.9 & 2010 \\
\hline 17 & Brazil & 51.9 & 2012 \\
\hline 18 & Papua New Guinea & 50.9 & 1996 \\
\hline 19 & Zambia & 50.8 & 2004 \\
\hline 20 & Swaziland & 50.4 & 2001 \\
\hline Source: Central Intelligence Agency. & & \\
\hline & & & \\
\hline
\end{tabular}

Finally, property prices may also react to the gains perspective of real estate owners, and rising prices can be the result of a bandwagon effect (Leibenstein, 1950; Becker, 1991). A "self-fulfilling prophecy" may occur, which may induce "a false definition of the situation evoking a new behavior which makes the originally false conception come true" (Merton, 1948).

In addition to those factors, the reduction of the interest rate and the release of mortgages by the federal government also offer investors a solid environment for investment because of "solvable demand" (Fig. 5.3). Real interest rates are currently close to zero.

Fig. 5.3 Real Interest Rates in Brazil and Rio de Janeiro Housing Asking Prices and Rent Percent Change

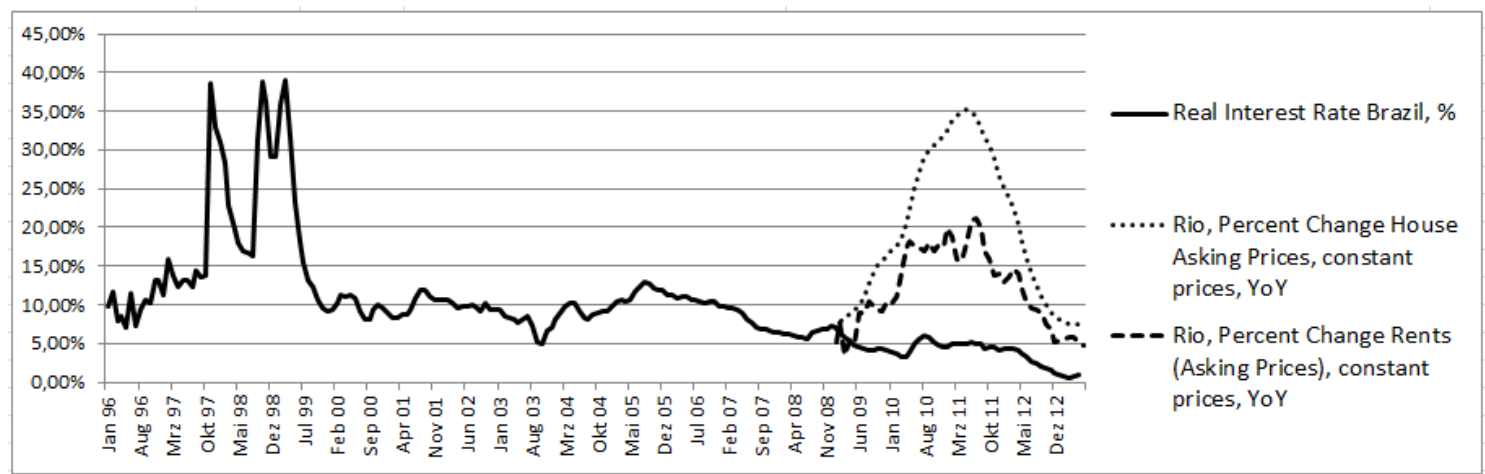


However, the actual basis of economic growth does not match the rise in housing prices. Fig. 5.4 displays Brazilian GDP growth and compares it with the increase in real estate prices.

Fig. 5.4 GDP per Capita, Construction Cost and Real Estate Prices in Brazil - Real Terms (Aug 2010 = 100)

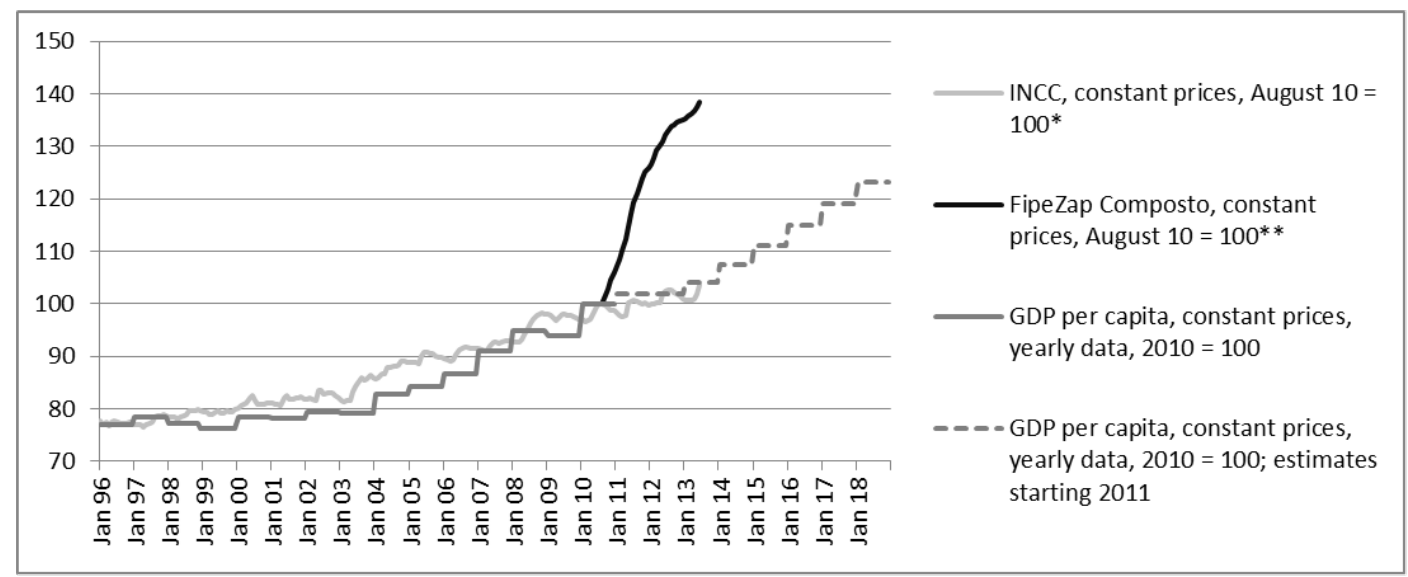

* INCC - National Construction Cost Index

** The Real Asking Prices began to be collected in Brazil since 2008 in Rio de Janeiro and Sao Paulo. Only in August 2010, the sample was amplified and FIPEZAP Composto could be calculated. The FIPEZAP Composto Index covers: Rio de Janeiro, Sao Paulo, Belo Horizonte, Distrito Federal, Recife, Fortaleza and Salvador.

Source: World Bank, FIPEZAP 2013.

The development of real estate prices in Rio de Janeiro is even more pronounced (Fig. 5.5). While Brazilian prices grew by 38.6\% (deflated) between August 2010 and June 2013 , prices in Rio grew by $58.3 \% .{ }^{24}$ The rental prices, although they did not rise as much as the sale prices, are also above the general income level.

Fig. 5.5 Price-Rent Comparison, Rio de Janeiro in Real Terms (August $2010=100$ )*

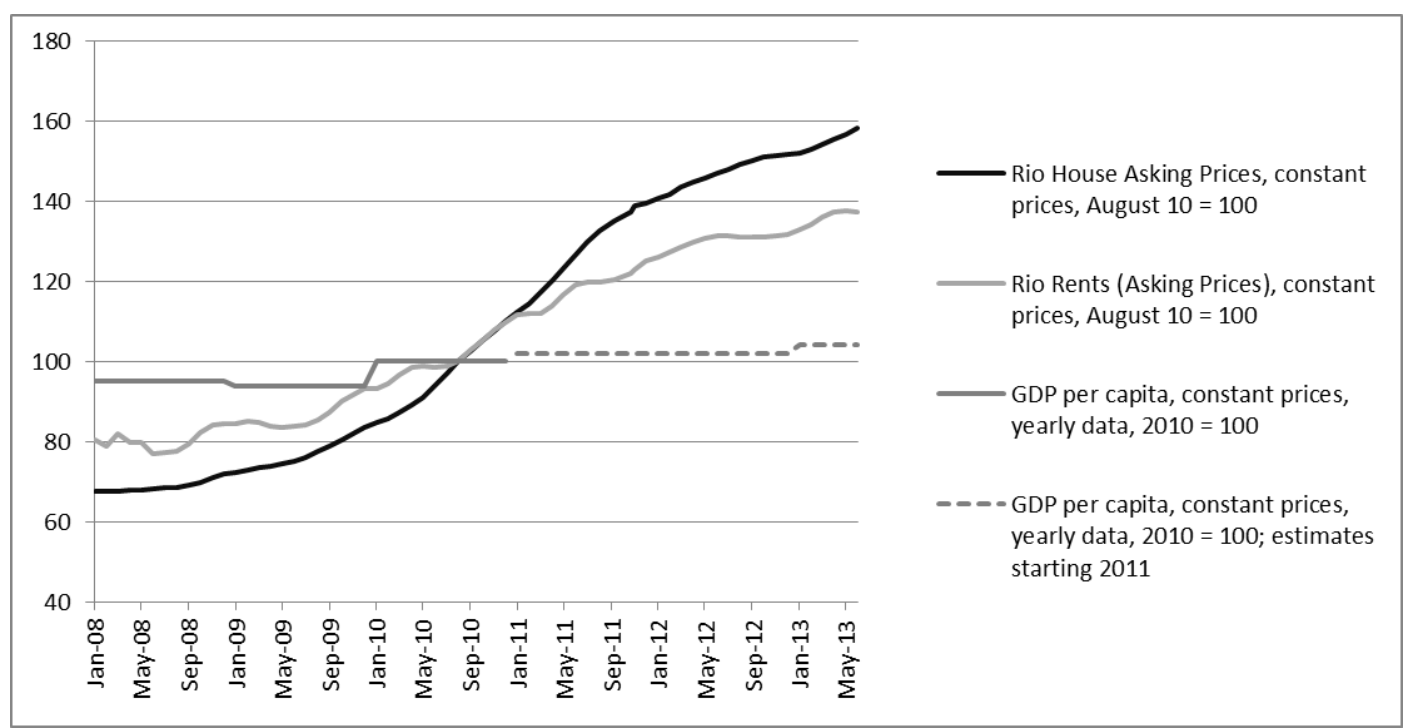

* Rio Asking prices are available since Jan/2008

Source: World Bank, FIPEZAP 2013.

${ }^{24}$ The FIPEZAP index measures the performance of real estate prices in Brazil. It does not control for important characteristics of the individual properties, such as maintenance. 
The calculation of the affordability of real estate is less straightforward in Brazil because the My House My Life Program provides mortgages with interest rates depending on family income: mortgages for households with an income between 0-3 times the minimum wage (WG), 3-6 times WG, 6-10 times WG and over10 times WG.

The Brazilian Housing Affordability Index can be calculated for the different wage groups $i$ as follows:

$$
H A I=\frac{\text { Income } i}{\text { Housing Price } \times \text { Interest Rates } i}
$$

where Income $i$ is the (index of) per capita income (nominal), Interest Rates $i$ are the income group specific nominal annual mortgage interest rates in \% provided by My House My Life Program and Housing Price is the (index of) Housing Price. (The index of the) Income per capita was approximated by the index of the minimum wage for lowest income groups (0-3 times minimum wage) and by (the index of the) nominal GDP per capita for the other income groups.

Calculating this index for the period 2009-2012 indicates that the real estate purchasing power of all income groups decreased considerably between 2009 and 2011 (Fig. 5.6). In 2012, the government authorized a 1\% decrease in interest rates for mortgages, providing better conditions for housing purchases. Furthermore, the levels of housing appreciation slowed down, presenting descending appreciation rates of 26,3\%, 13,7\% and 2,7\% for 2011, 2012 and 2013, in real terms respectively. ${ }^{25}$

\section{Fig. 5.6 Housing Affordability Index}

\begin{tabular}{|c|c|c|c|c|c|}
\hline & 2009 & 2010 & 2011 & 2012 & $2013(p)$ \\
\hline \multicolumn{6}{|l|}{ Affordability Brazil } \\
\hline Affordability 0-3 times minimal wage & n.a. & 100,0 & 82,4 & 96,6 & n.a \\
\hline Affordability for 3-6 times minimal wage & n.a. & 100,0 & 84,0 & 83,9 & n.a \\
\hline Affordability 6-10 times minimal wage & n.a. & 100,0 & 84,0 & 81,9 & n.a \\
\hline Affordability up 10 times minimal wage & n.a. & 100,0 & 84,0 & 80,7 & n.a \\
\hline \multicolumn{6}{|l|}{ Affordability Rio } \\
\hline Affordability 0-3 times minimal wage & 123,0 & 100,0 & 75,1 & 86,6 & 89,6 \\
\hline Affordability for 3-6 times minimal wage & 116,9 & 100,0 & 76,6 & 75,2 & 73,0 \\
\hline Affordability 6-10 times minimal wage & 116,9 & 100,0 & 76,6 & 73,5 & 71,3 \\
\hline Affordability up 10 times minimal wage & 116,9 & 100,0 & 76,6 & 72,4 & 70,2 \\
\hline
\end{tabular}

The aforementioned particularity of the Rio de Janeiro real estate price development could be related to the World Cup scheduled for 2014 and the Olympics in 2016. However, Fig. 5.7 illustrates that major non-World Cup cities (NWWC) have been hit just as hard by price increases as World Cup cities (WCC). The unweighted index of prices in World Cup cities does not show greater appreciation than in non-World Cup cities (Fig 5.8).

\footnotetext{
${ }^{25}$ Calculations are available from the authors on request.

*WCC: São Paulo, Rio de Janeiro, Belo Horizonte, Brasília, Recife, Fortaleza, Salvador, Porto Alegre and Curitiba.

${ }^{* *}$ NWCC: Santo André, São Bernado do Campo, São Caetano do Sul, Niterói, Vitória, Vila Velha and Florianópolis.
} 
Fig. 5.7 Real Estate Price Index; June2012=100

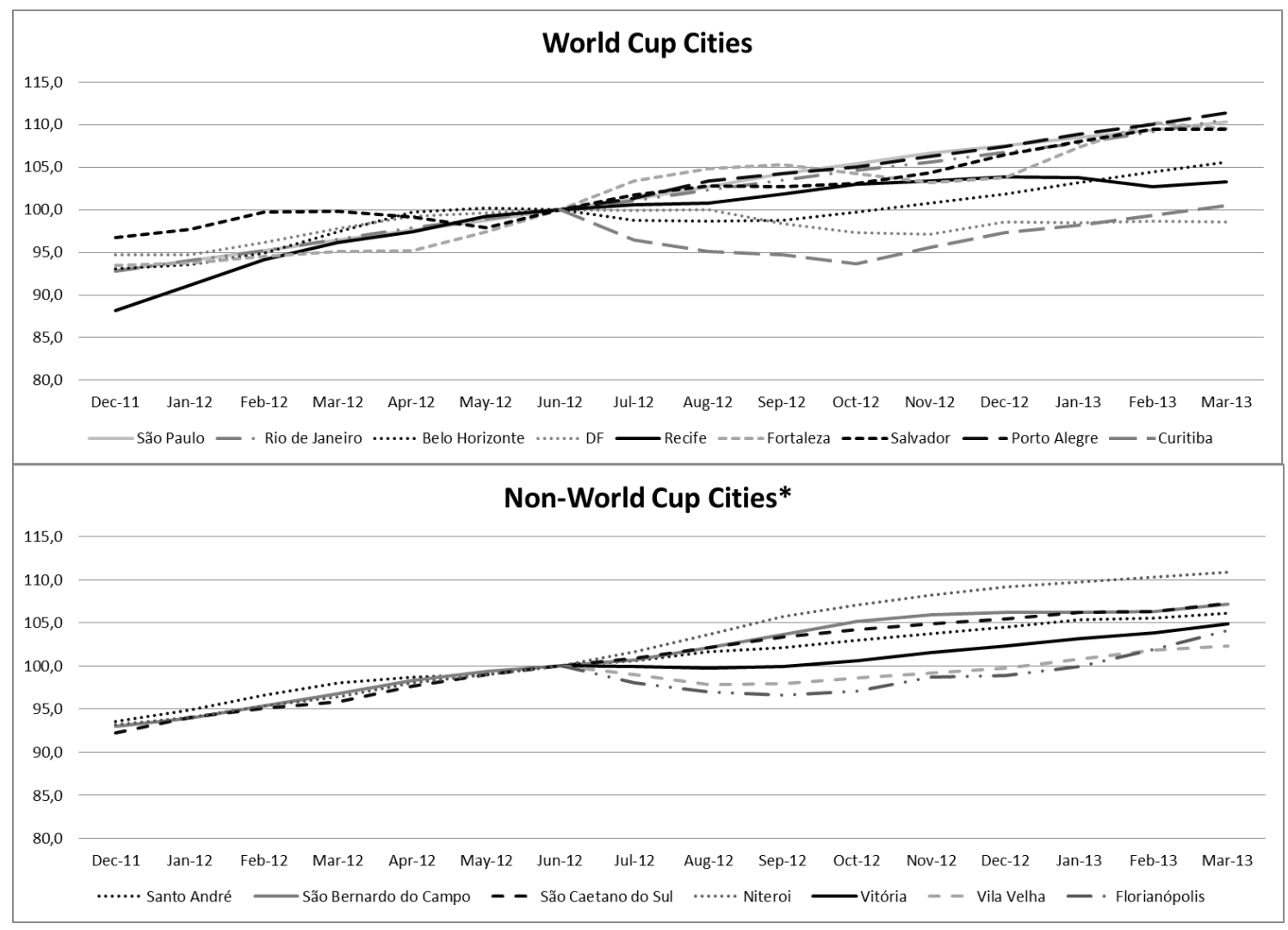

* Santo André, São Bernardo do Campo, São Caetano do Sul e Niterói may suffer the influence of Rio de Janeiro and São Paulo markets due to geographic proximity.

Source: FIPEZAP 2013.

Fig. 5.8 Nominal Asking Prices in World Cup Cities (WCC) and Non-World Cup Cities (NWCC)*

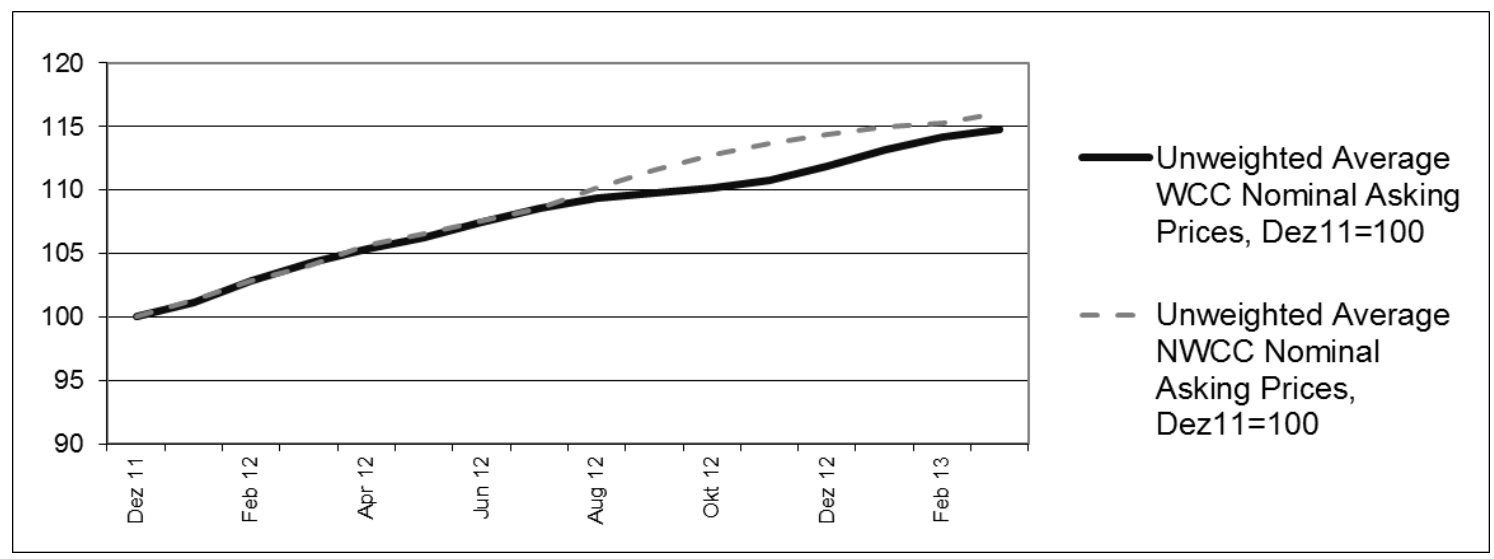

* Santo André, São Bernardo do Campo, São Caetano do Sul and Niterói may suffer the influence of Rio de Janeiro and São Paulo markets due to geographical proximity. Until December 2011, the FIPEZAP Index was composed of the host cities of World Cup. Since then, other municipalities that are not host cities have become part of the calculation of the index FIPEZAP.

Source: FIPEZAP 2013.

The regional GDP growth rates were not significantly different between 2007 (the year in which Brazil was elected host of the World Cup) and 2010 for the 12 states hosting the World Cup and for the 15 states not hosting the World Cup. ${ }^{26}$ To be

${ }^{26}$ Calculations are available from the authors on request. 
sure, the (official) spending of 26.5 billion R\$ for the World Cup and 7.4 billion R\$ for the Olympics ${ }^{27}$ equal some 0.15\%of the Brazilian GDP between 2007 and 2016. Compared to Brazilian GDP growth rates, this impulse seems to be negligible. Any impulse for infrastructure induced by mega-sport events is obviously so small that it cannot directly explain the real estate price development.

\section{Conclusions}

The spread of the strategic planning method in Brazil during the1990s has contributed to the widespread perception that the realization of mega events may serve local development. During the 1990s and 2000s, many efforts were awarded by the confirmation of several international events in the country. Among them, major sporting events stand out.

For the realization of these events, large sums of public funds have been invested in urban infrastructure and logistics, bringing changes in the social, political and economic dynamics of Rio de Janeiro. Despite the precariousness in various sectors, the state also assisted the real estate sector by subsidizing the reliability of investments in the housing market through the launch of new mortgage programs and investments for infrastructure projects. One of the main urban effects refers to the variation in property prices, generating processes of gentrification and urban segregation. While Brazilian real prices grew by $38.58 \%$ (deflated) between August 2010 and June 2013, real prices in Rio grew by $58.30 \%$ compared with a real income growth of $4.12 \%$ in Brazil.

However, this inflationary phenomenon occurs in most Brazilian cities, including non-host cities. In sum, housing became less affordable between 2009 and 2011, but since then, the decrease of interest rates has pushed the market to affordable levels. Within this framework, the appreciation of real estate is explained largely by population and economic growth and the reduction of interest rates through mortgage programs, as well as reduced social inequality.

Urban policy based on strategic plans and housing policy promoted by home loans leaves a legacy of socio-spatial segregation, which assisted in the emergence of protests against the realization of mega sporting events, including those that occurred in Brazil during the Confederations Cup in 2013. (Official) public investments in mega events account for only approximately $0.15 \%$ of Brazilian GDP from 2007 to 2016 and are thus hardly responsible for the precariousness in social services.

In this sense, we need to rethink the model of social legacy adopted when carrying out mega sporting events and enable proposals that are more compatible with the local reality. The perceived lack of public accountability for mega event finances as well as the perceived lack of susceptibility to social issues by the mega sporting projects due to the submission policies to determinations of

*WCC: São Paulo, Rio de Janeiro, Belo Horizonte, Brasília, Recife, Fortaleza, Salvador, Porto Alegre and Curitiba.

${ }^{* *}$ NWCC: Santo André, São Bernado do Campo, São Caetano do Sul, Niterói, Vitória, Vila Velha and Florianópolis.

${ }^{27}$ Data source: http://www.portaltransparencia.gov.br/rio2016/. 
FIFA and the IOC may harm the public opinion of mega events. International sporting federations should thus have every interest in ensuring that their mega events target social inclusion and pay more attention to the needs of local urban, environmental and social policies that adhere to the aspirations of generations, which are shaped by social media, instant publicity, and ease ("like it"), but seemingly effective participation instead of adopting models and strategic plans that were developed for earlier social realities.

\section{Literature}

ARANTES, O. / VAINER, C. / MARICATO, E. (2000), A cidade do Pensamento Único: desmanchando consensos. Petrópolis. RJ: Vozes.

BECKER, G. (1991), A note on restaurant pricing or other examples of social influences onprice. Journal of Political Economy 99, 1109-1116.

BROUDEHOUX, A. (2007), Spectacular Beijing: The conspicuous construction of an Olympic metropolis. Journal of Urban Affairs 29, 383-399.

BORJA, J. / CASTELLS, M. (1997), Local and Global. Londres, Earthscan.

BOTELHO, A. (2007), O urbano em fragmentos: a produção do espaço e da moradia pelas práticas do setor imobiliário. São Paulo: Annablume, FAPESP.

CARDOSO, A. L. / ARAGÃO, T. A. / ARAUJO, F. S. (2011), Habitação de Interesse Social: política ou mercado? Reflexos sobre a construção do espaço metropolitan, in: XIII Encontro Nacional da ANPUR, 2011, Rio de Janeiro. Anais do XIII EncontroNacional da ANPUR.

COCHRANE, A. / PECK, J. / TICKELL, A. (1996), Manchester plays games: Exploring the local politics of globalisation. Urban Studies 33, 1319-1336.

CUTLER, D. M. / GLASER, E. L. (1997), Are Guetos Good or Bad? Quarterly Journal of Economics 112, 827-872.

DUST, L. / MAENNIG, W. (2008), Shrinking and Growing Metropolitan Areas - Asymmetric Real Estate Price Reactions? The Case of German Single-Family Houses. Regional Science and Urban Economics 38, 63-69.

ESSEX S. / CHALKLEY, B. (2004), Mega-sporting events in urban and regional policy: A history of the Winter Olympics. Planning Perspectives 19, 201-232.

FIX, M. (2001), Parceiros da Exclusão: duas histórias da construção de uma "nova cidade" em São Paulo: Faria Lima e Água Espraiada. São Paulo: Boitempo.

GOLD, J. / GOLD, M. (2008), Olympic cities: Regeneration, city branding, and changing urban agendas. Geography Compass 2, 300-318.

GAFFNEY, C. / OMENA, E. (2010), Mega-eventos esportivos: reestruturação urbana para quem. Proposta (Rio de Janeiro) 120, 51-73.

GOTHAM, D. (2005), Theorizing urban spectacles: Festivals, tourism, and the transformation of urban space. City 9, 225-246.

HADDAD, E. / MEYER, J. (2012), Global Markets: crises, policies, and institutions, in: A. Bardhan, R. Edelstein, C. Kroll (Eds), Global Markets: crises, policies, and institutions. John Wiley \& Sons Inc., Hoboken, New Jersey.

HARVEY, D. O. (2009), Novo imperialismo, 3a. ed. Traduzido por Adail Sobral e Maria Stela Gonçalves. São Paulo: Edições Loyola. 
HILLER, H. H. / WANNER, R. A. (2010), Public Opinion in Host Olympic Cities: The Case of the 2010 Vancouver Winter Games, Sociology 45, 883-899.

KAIN, J. F. (1968), Housing segregation, Negro employment, and metropolitan decentralization. Quarterly Journal of Economics 82, 175-197.

KOWARICK, L. (1993), A espoliação urbana. Rio de Janeiro: Paz e Terra.

LEAL, J. A. (1999), Financiamento do investimento em habitação: requisitos para uma estrutura funcional. Tese de doutoramento, Rio de Janeiro, UFRJ, IE.

LEIBENSTEIN, H. (1950), Bandwagon, Snob and Veblen effects in the theory of consumersdemand, Quarterly Journal of Economics 64, 183-207.

MANKIW, N. G., / WEIL, D. N. (1989), The baby boom, the baby bust, and the housing market, Regional Science and Urban Economics 19, 235-258.

MARICATO, E. (1979), A produção capitalista da casa (e da cidade) no Brasil Industrial. São Paulo: Editora Alfa-Omega LTDA.

MERTON, R. K. (1948), The self-fulfilling prophecy. Antioch review 8, 193-210.

PEREIRA, L. / BRESSER, C. (1990), Da inflação à hiperinflação: uma abordagem estruturalista, in: J. M. Rego, org., Inflação e Hiperinflação -Interpretações e Retórica, São Paulo: Bienal, 7-28.

PRESIDÊNCIA DA REPÚBLICA (2010), Plano Nacional de Habitação de Interesse Social PLANHHAB, Brasília.

RUBIO, K. (2005), Os jogos olímpicos e a transformação das cidades: os custos sociais de um megaevento. ScriptaNova. Revista electrónica de geografía y ciencias sociales. Barcelona: Universidad de Barcelona, 1 de agostode, IX, núm. 194.

SHORT, J. (2008), Globalization: Cities and the Summer Olympics. City 12, 321-340.

TOMLINSON, A. (2005), The commercialization of the Olympics: Cities, corporations and the Olympic commodity, in: K. Young and K. Wamsley (Eds), Global Olympics: Historical and Sociological Studies of the Modern Games. London: Elsevier, pp. 179200.

WEINBERG, B. (2000), Black residential Centralization and Spatial Mismatch Hypothesis, Journal of Urban Economics 48, 110-134. 


\section{Hamburg Contemporary Economic Discussions}

(Download: http://www.uni-hamburg.de/economicpolicy/hced.html)

ARAGÃO, T. / MAENNIG, W.: Mega Sporting Events, Real Estate, and Urban Social Economics - The Case of Brazil 2014/2016, 2013.

MAENNIG, W. / STEENBECK, M. / WILHELM, M.: Rhythms and Cycles in Happiness, 2013.

RICHTER, F. / STEENBECK, M. / WILHELM, M.: The Fukushima Accident and Policy Implications: Notes on Public Perception in Germany, 2014 (2 $2^{\text {nd }}$ version).

MAENNIG, W.: London 2012 - das Ende des Mythos vom erfolgreichen Sportsoldaten, 2012.

MAENNIG, W. / WELLBROCK, C.: London 2012 - Medal Projection Medaillenvorausberechnung, 2012.

MAENNIG, W. / RICHTER, F.: Exports and Olympic Games: Is there a Signal Effect? 2012.

MAENNIG, W. / WILHELM, M.: Becoming (Un)employed and Life Satisfaction: Asymmetric Effects and Potential Omitted Variable Bias in Empirical Happiness Studies, 2011.

MAENNIG, W.: Monument Protection and Zoning in Germany: Regulations and Public Support from an International Perspective, 2011.

BRANDT, S. / MAENNIG, W.: Perceived Externalities of Cell Phone Base Stations - The Case of Property Prices in Hamburg, Germany, 2011.

MAENNIG, W. / STOBERNACK, M.: Do Men Slow Down Faster than Women? 2010.

DU PLESSIS, S. A. / MAENNIG, W.: The 2010 World Cup High-frequency Data Economics: Effects on International Awareness and (Self-defeating) Tourism, 2010.

BISCHOFF, O.: Explaining Regional Variation in Equilibrium Real Estate Prices and Income, 2010.

FEDDERSEN, A. / MAENNIG, W.: Mega-Events and Sectoral Employment: The Case of the 1996 Olympic Games, 2010.

FISCHER, J.A.V. / SOUSA-POZA, A.: The Impact of Institutions on Firms Rejuvenation Policies: Early Retirement with Severance Pay versus Simple Lay-Off. A Cross-European Analysis, 2010. 


\section{Hamburg Contemporary Economic Discussions}

(Download: http://www.uni-hamburg.de/economicpolicy/hced.html)

33

FEDDERSEN, A. / MAENNIG, W.: Sectoral Labor Market Effects of the 2006 FIFA World Cup, 2010.

AHLFELDT, G.: Blessing or Curse? Appreciation, Amenities, and Resistance around the Berlin "Mediaspree", 2010.

FALCH, T. / FISCHER, J.A.V.: Public Sector Decentralization and School Performance: International Evidence, 2010.

AHLFELDT, G. / MAENNIG, W. /ÖLSCHLÄGER, M.: Lifestyles and Preferences for (Public) Goods: Professional Football in Munich, 2009.

FEDDERSEN, A. / JACOBSEN, S. / MAENNIG, W.: Sports Heroes and Mass Sports Participation - The (Double) Paradox of the "German Tennis Boom", 2009.

AHLFELDT, G. / MAENNIG, W. / OSTERHEIDER, T.: Regional and Sectoral Effects of a Common Monetary Policy: Evidence from Euro Referenda in Denmark and Sweden, 2009.

BJØRNSKOV, C. /DREHER, A. /FISCHER, J.A.V. /SCHNELLENBACH, J.: On the Relation Between Income Inequality and Happiness: Do Fairness Perceptions Matter? 2009.

AHLFELDT, G. / MAENNIG, W.: Impact of Non-Smoking Ordinances on Hospitality Revenues: The Case of Germany, 2009.

FEDDERSEN, A. / MAENNIG, W.: Wage and Employment Effects of the Olympic Games in Atlanta 1996 Reconsidered, 2009.

AHLFELDT, G. / FRANKE, B. / MAENNIG, W.: Terrorism and the Regional and Religious Risk Perception of Foreigners: The Case of German Tourists, 2009.

AHLFELDT, G. / WENDLAND, N.: Fifty Years of Urban Accessibility: The Impact of Urban Railway Network on the Land Gradient in Industrializing Berlin, 2008.

AHLFELDT, G. / FEDDERSEN, A.: Determinants of Spatial Weights in Spatial Wage Equations: A Sensitivity Analysis, 2008.

MAENNIG, W. /ALLMERS, S.: South Africa 2010: Economic Scope and Limits, 2008. 


\section{Hamburg Contemporary Economic Discussions}

(Download: http://www.uni-hamburg.de/economicpolicy/hced.html)

MAENNIG, W. / WELLBROCK, C.-M.: Sozio-ökonomische Schätzungen Olympischer Medaillengewinne: Analyse-, Prognose- und Benchmarkmöglichkeiten, 2008.

AHLFELDT, G.: The Train has Left the Station: Real Estate Price Effects of Mainline Realignment in Berlin, 2008.

MAENNIG, W. / PORSCHE, M.: The Feel-good Effect at Mega Sport Events - Recommendations for Public and Private Administration Informed by the Experience of the FIFA World Cup 2006, 2008.

AHLFELDT, G. / MAENNIG, W.: Monumental Protection: Internal and External Price Effects, 2008.

FEDDERSEN, A. / GRÖTZINGER, A. / MAENNIG, W.: New Stadia and Regional Economic Development - Evidence from FIFA World Cup 2006 Stadia, 2008.

AHLFELDT, G. / FEDDERSEN, A.: Geography of a Sports Metropolis, 2007.

FEDDERSEN, A. / MAENNIG, W.: Arenas vs. Multifunctional Stadia - Which Do Spectators Prefer? 2007.

AHLFELDT, G.: A New Central Station for a Unified City: Predicting Impact on Property Prices for Urban Railway Network Extension, 2007.

AHLFELDT, G.: If Alonso was Right: Accessibility as Determinant for Attractiveness of Urban Location, 2007.

AHLFELDT, G., MAENNIG, W.: Assessing External Effects of City Airports: Land Values in Berlin, 2007.

MAENNIG, W.: One Year Later: A Re-Appraisal of the Economics of the 2006 Soccer World Cup, 2007.

HAGN, F. / MAENNIG, W.: Employment Effects of the World Cup 1974 in Germany.

HAGN, F. / MAENNIG W.: Labour Market Effects of the 2006 Soccer World Cup in Germany, 2007.

JASMAND, S. / MAENNIG, W.: Regional Income and Employment Effects of the 1972 Munich Olympic Summer Games, 2007.

DUST, L. / MAENNIG, W.: Shrinking and Growing Metropolitan Areas Asymmetric Real Estate Price Reactions? The Case of German Singlefamily Houses, 2007. 


\section{Hamburg Contemporary Economic Discussions}

(Download: http://www.uni-hamburg.de/economicpolicy/hced.html)

05

04

03

02

01

$04 / 2006$

$03 / 2006$

$02 / 2006$

$01 / 2006$

$04 / 2005$

03/2005

$02 / 2005$
HEYNE, M. / MAENNIG, W. / SUESSMUTH, B.: Mega-sporting Events as Experience Goods, 2007.

DU PLESSIS, S. / MAENNIG, W.: World Cup 2010: South African Economic Perspectives and Policy Challenges Informed by the Experience of Germany 2006, 2007.

AHLFELDT, G. / MAENNIG, W.: The Impact of Sports Arenas on Land Values: Evidence from Berlin, 2007.

FEDDERSEN, A. / MAENNIG, W. / ZIMMERMANN, P.: How to Win the Olympic Games - The Empirics of Key Success Factors of Olympic Bids, 2007.

AHLFELDT, G. / MAENNIG, W.: The Role of Architecture on Urban Revitalization: The Case of "Olympic Arenas" in Berlin-Prenzlauer Berg, 2007.

MAENNIG, W. / SCHWARTHOFF, F.: Stadium Architecture and Regional Economic Development: International Experience and the Plans of Durban, October 2006.

FEDDERSEN, A. / VÖPEL, H.: Staatliche Hilfen für Profifußballclubs in finanziellen Notlagen? - Die Kommunen im Konflikt zwischen Imageeffekten und Moral-Hazard-Problemen, September 2006.

FEDDERSEN, A.: Measuring Between-season Competitive Balance with Markov Chains, July 2006.

FEDDERSEN, A.: Economic Consequences of the UEFA Champions League for National Championships - The Case of Germany, May 2006.

BUETTNER, N. / MAENNIG, W. / MENSSEN, M.: Zur Ableitung einfacher Multiplikatoren für die Planung von Infrastrukturkosten anhand der Aufwendungen für Sportstätten - eine Untersuchung anhand der FußballWM 2006, May 2005.

SIEVERS, T.: A Vector-based Approach to Modeling Knowledge in Economics, February 2005.

SIEVERS, T.: Information-driven Clustering - An Alternative to the Knowledge Spillover Story, February 2005. 


\section{Hamburg Contemporary Economic Discussions}

(Download: http://www.uni-hamburg.de/economicpolicy/hced.html)

01/2005 FEDDERSEN, A. / MAENNIG, W.: Trends in Competitive Balance: Is there Evidence for Growing Imbalance in Professional Sport Leagues? January 2005. 


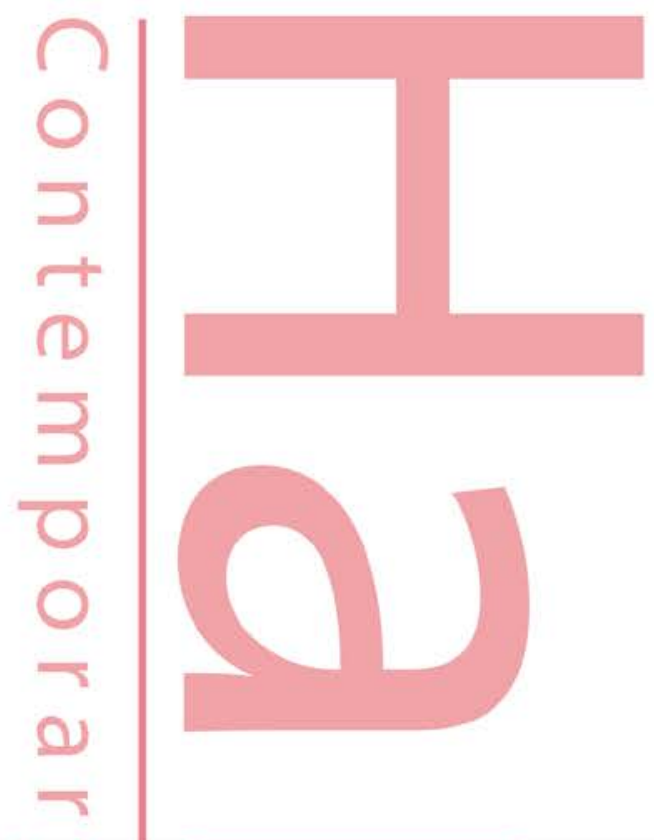

ISSN 1865-2441 (PRINT) ISSN 1865-7133 (ONLINE)

ISBN 978-3-942820-08-O (PRINT) ISBN 978-3-942820-09-7 (ONLINE) 